of 1969 did the work begin that demonstrated the presence of the enzyme. Nor did Temin (or Baltimore) "isolate" the enzyme as Thompson writes. A page later, he asserts that Baltimore, at 35 in 1975 , was "the youngest person ever to win the Nobel". No! That was and remains Lawrence Bragg, who had the prize in his pocket in 1915 at the age of 25 , while many others had received theirs younger than 35, for example Paul Dirac (at 31), Tsung-Dao Lee (31) and Watson (34).

There has been a need for a competent primer in modern genetics, written for the serious nonspecialist: Paul Berg and Maxine Singer have provided it. They collaborated earlier on a textbook, Genes and Genomes. Dealing with Genes began as a derivative, but in the writing evolved independently. The result still looks and feels like a textbook, in shape, design and illustration scheme. Their prose is without personality - but that's deliberate, and the book is clear and thorough. It comes in at the right level: it dispenses with the stupefying detail that the student requires, and as a result the bone-structure of the science shows through. The material that is here will age more gracefully than does the full-scale textbook.

The same publisher, University Science Books, has now issued an ambitious, complex and in some ways weird book, which as its title says bears down on the human genome project. This, again, looks like a textbook - a flashy one, large pages printed on stock of various colours and with lots of full-colour artwork and photographs, one even in 3D. It is also a compendium, and of disparate materials by diverse hands - some 50 authors all told. We are told that Necia Grant Cooper, its editor (compiler?) is trained in the physical sciences and works at Los Alamos. A 65 -page introduction to genetics is by a

\section{New in paperback}

The Red Queen: Sex and the Evolution
of Human Nature by Matt Ridley.
Penguin, $£ 7.99$. "There is a wealth of
information here and [the book] is an
excellent source for researchers
because of the descriptions of studies
and its extensive reference section, as
well as being interesting to a
scientifically literate public. Enter-
taining... the quality of the writing only
rarely falters" (Magnus Enquist and Risa
Rosenberg. Nature 367,$697 ; 1994$ ).
Models for Embryonic Periodicity by
Lewis I. Held Jr. Karger, $£ 15, \$ 24$,
SFr30, DM36. "Held has brought his
incisive intelligence and background in
computer programming to bear on a
whole menagerie of models. He has
scoured the literature with evident
enthusiasm. The result is a very useful
guide" (Peter A. Lawrence, Nature $\mathbf{3 5 8}$,
$720 ; 1992$ ).

single contributor, but is presented for the most part in a series of 19 full-page 'boxes', in pure US textbook style. This is followed by a 'round table' in which nine prominent scientists, from Baltimore to Wexler and Norton Zinder, wax sententious about "the vision, the science, the implementation" of the genome project, in brief, alternating, heavily edited bursts punctuated by mug shots of the participants. Yet these are followed by four straightforward chapters on the methods, aims and implications of the project. A later chapter, about a specialized new method of sequencing, is five pages long and lists 16 authors. The whole thing is as jumpy and overproduced as a rock-music video, which perhaps defines the generation at which it is aimed.

(University Science Books is worth keeping in mind. Located in Marin County, just north of San Francisco, it is a small house, whose founder, Bruce Armbruster, apparently intends that it should grow into the large, empty niche left in science publishing on the West Coast by the relocation of W. H. Freeman, some years ago, to New York.)

The genome project had all sorts of scientific origins and has been from the beginning the product of politics within science and the interaction of science with politics on the larger scene, in California and Massachusetts, in England and France, but especially in Washington and it surroundings. No one person is in a position to write about all of this firsthand, but Robert Cook-Deegan comes as close as any. He is a physician by training and not a scientist. For crucial years in the mid-1980s, he worked at the Office of Technology Assessment (OTA), a creature of the US Congress, set up to conduct extended studies, at the request of committee chairmen, of anything from, say, coal mining to ozone depletion. There, Cook-Deegan directed projects including one on gene therapy and another, the big one, on the genome project. "Our task at OTA was to report to Congress on what the genome project was, whether or not it was worth funding, and how its underlying bureaucracy should be constructed," he writes. "This vantage point placed me in the midst of three groups: scientists debating the merits of genome projects, administrators working in federal agencies responsible for funding the scientists, and members of Congress who had the constitutional authority to specify how much and in what way federal funds could be used." Cook-Deegan's team was tiny, clever and agile; as the OTA is not part of the federal government they were mostly free of interagency rivalries. Their report, Mapping Our Genes - Genome Projects: How Big? How Fast?, issued in 1988, was itself crucial to the founding of the project. And he got to observe most of the players and much of the action. He has mastered the documents and conducted scores of interviews.

The Gene Wars is a scrupulous and immensely particular narrative of the genesis and opening years of the genome projects. Cook-Deegan is cogent about the balance of scientific, biomedical and commercial motivations, since he is copious in narrating people's actions yet cautious in judging them. Deliciously dry, for example, is the passage about the interactions of Watson and Bernadine Healy, when he was coordinator of genome research for the National Institutes of Health and she the institutes' director manoeuvring to force him out. The Gene Wars is often intricate, sometimes stylistically lumpy, but it is an essential history.

To marvel, to teach, to warn - the one recent book that does all three, and with an individual voice and cool wisdom, is Robert Pollack's Signs of Life. Pollack is a molecular and cell biologist of deserved reputation, and an extraordinary teacher. Many scientists are thoughtful and widely read outside their specialties: Pollack is of the rare kind whose science itself is permeated and in part shaped by a profound historical, literary and critical sensibility. $\mathrm{He}$ is also one of biology's great worriers. It was his telephone call from Cold Spring Harbor to Berg at Stanford in the summer of 1971, about the potential dangers in certain experiments in the then-infant field of recombinant DNA, which set in motion the train of events leading to the moratorium on such research in the summer of 1974 and the Asilomar conference in the spring of 1975. In Signs of Life, Pollack's controlling metaphor is that genomes are texts written in DNA, that cells read, edit and select from these texts, and that the grand enterprise of genetics is to read, understand, interpret and perhaps ourselves edit these texts. In his ingenious and supple elucidation of his science, the metaphor works. This is a book that welcomes readers in and, by the end, invites them to consider the limitations of the science, some technical, some prudential, some ethical. Pollack thus rises to the level of Macfarlane Burnet and Peter Medawar: Signs of Life is the most distinguished book about science I have seen so far this decade. It is also a sensuous delight to read.

Horace Freeland Judson is in the Program in History and Philosophy of Science, Stanford University, Stanford, California 94305, USA.

Also recently published is The Book of Man: The Quest to Discover Our Genetic Heritage by Walter Bodmer and Robin McKie (Little, Brown, £18.99). The authors chart the origins and progress of the Human Genome Project, and provide an optimistic assessment of the potential implications of this research. 